\title{
Explaining the failure of the Dutch innovation system for biomass digestion-A functional analysis
}

\author{
Simona O. Negro*, Marko P. Hekkert, Ruud E. Smits \\ Department of Innovation Studies, Copernicus Institute for Sustainable Development and Innovation, Faculty of Geo-sciences, Utrecht University, \\ Heidelberglaan 2, 3584 CS Utrecht, The Netherlands
}

Available online 24 March 2006

\begin{abstract}
Since the 1970s research on energy conversion technologies, such as biomass digestion, has been carried out in the Netherlands. However, after 30 years biomass digestion has not been implemented on large scale. The aim of this paper is to create insight into the underlying factors of this troublesome trajectory by applying the 'Functions of Innovation Systems' framework. This results in clear understanding of the (lack of) activities that took place in the innovation system of biomass digestion and the role of government policy in both inducing and blocking this development. The analysis provides several lessons to take into account when developing policies for the acceleration of the development and diffusion of biomass energy.
\end{abstract}

(C) 2006 Elsevier Ltd. All rights reserved.

Keywords: System functions; Dynamics; Transitions

\section{Introduction}

Since the energy crises in the 1970s and the increased climate change awareness in the nineties, research has been carried out to find alternative energy sources to replace fossil fuels. One of the most promising alternatives is biomass. The potential of biomass is estimated in long term

Abbreviations: BSE, Resolution Subsidy Energy Programme; CE, Centre for Energy and Environment; CHP, combined heat and power; ECN, Energy Research Centre of the Netherlands; EWAB, energy production from waste and biomass; IMAG, agrotechnology and food innovation; LCCA, rural coordination commission for waste policy; LVK, Rural Sales Office; MEP, Environmental Quality Electricity Production; Ministry of EZ, Dutch Ministry of Economic Affairs; NMP, National Environmental Policy Plan; NOH, National Research Programme for recycling of waste; NOVEM, Netherlands Agency for Energy and Environment; PDE, Dutch Office for Renewable Energies; REB, regulating energy tax; RIVM, National Institute for Public Health and the Environment; SMB, Cooperation of Middle-Brabant County; TNO, Netherlands Organisation for Applied Scientific Research; TNO-MEP, TNO environment, energy and process innovation; VROM, Netherlands Ministry of Housing, Spatial Planning and the Environment

*Corresponding author. Tel.: +31 30 2537166; fax: + 31302532746 .

E-mail address: s.negro@geo.uu.nl (S.O. Negro). scenarios to contribute about $1135 \mathrm{EJ} /$ year (Hoogwijk, 2004). Biomass is a very diverse energy carrier with a multitude of potential sources and applications and it may be the main renewable energy alternative that could compete on large scale with fossil fuels. Even though the potential of biomass is clear, this does not imply that the implementation of biomass energy is easy. In the Netherlands for example realisation of the national goals regarding the use of biomass energy is far behind schedule. Therefore, in this paper we analyse the troublesome history of the development and application of a specific biomass conversion technology, i.e. biomass digestion, to learn lessons from the difficulties and problems that characterise this development during the last 30 years. Our main research question is therefore:

How can we explain the slow diffusion of biomass digestion technology in The Netherlands?

From earlier studies on the transformation of the energy system we have learned that the success of a new technology is not (only) determined by technological characteristics but (also) by the social system that develops, 
diffuses, implements or rejects new biomass technologies (Jacobsson and Bergek, 2004). We label this sociotechnical system as 'Technology Specific Innovation System' (TSIS).

The conceptual starting point of this paper is that a well functioning TSIS is a requirement for the technology in question to be developed and widely diffused. In fact diffusion cannot take place on a large scale without a well functioning TSIS. However, what determines whether an TSIS functions well or not and how do we know that is does so (apart from studying the diffusion of the technology)? In a recent stream of articles, of which a significant number in Energy Policy, it is brought forward that a number of activities are of great influence to this system functioning (Jacobsson and Johnson, 2000, 2001b; Johnson and Jacobsson, 2001; Sagar and Holdren, 2002; Foxon et al., 2005). These key activities are labelled as 'Functions of Innovation Systems'. In earlier empirical papers these functions are successfully used to describe the dynamics of innovation system development and deliver explanations for the success and failure of TSIS in different countries. However, most of these analyses lack a research design into which all relevant activities are mapped over time to create insight in the precise evolution of functional patterns. In this case study we apply a method called process analysis (or history event analysis) to create deeper insight in the dynamics of innovation systems by a detailed mapping of innovation system activities (Abbot, 1995). The empirical case of biomass digestion in The Netherlands is reported before (Raven, 2004). It provided valuable insights in terms of how structural factors like the development of the socio-technical landscape and the impact of mismatched rule-sets influenced the diffusion of digestion technology. In this article we aim to add to these insights by focusing on the resulting patterns of activities that took place. We expect that structural factors and activities influence each other mutually.

Therefore the aim of this paper is not only to learn lessons from the unsuccessful story of biomass digestion but also to test the 'Functions of Innovation Systems' approach by applying it in an innovative manner to structure empirical work so that complementary insights to previous work can be generated in order to provide complementary insights to previous work (Jacobsson and Johnson, 2000; Raven, 2004).

The paper is structured as follows. In Section 2 an overview of the background of the Innovation System approach and the 'Functions of Innovation Systems' concept will be given with a focus on the functions that will be used in this paper. In Section 3 the methodology and the technical aspects will be described. In Section 4 the event description of biomass digestion and in Section 5 the function fulfilment will be analysed. Section 6 contains lessons from (a) a methodological perspective and (b) from a policy perspective building on a richer understanding of the activities and the lack of activities that took place.

\section{Analytical framework}

\subsection{Technological change and innovation systems}

The underlying theory of this paper focuses on the 'lockin' of established systems and the difficulty that firms encounter when they want to develop a new technology and bring it to the market (Unruh, 2000, 2002). It is argued in Unruh (2000) that "industrial economies have been locked into fossil fuel-based energy systems through a process of technological and institutional co-evolution driven by path-dependant increasing returns to scale." $\mathrm{He}$ calls this condition 'carbon lock-in' since it creates persistent market and policy failures that inhibit the diffusion of carbon-saving technologies despite their apparent environmental and economic advantages. Unruh (2000) argues further that the "lock-in occurs through combined interactions among technological systems and governing institutions, which perpetuate fossil fuel-based infrastructure in spite of their known environmental externalities and the apparent existence of cost-neutral, or even cost-efficient, remedies". These technological systems have to be seen as large complex systems of technologies embedded in a powerful conditioning social context of public and private institutions. To avoid confusion with other definitions of technological systems (Hughes, 1983) we label these systems as 'TSIS', which are defined as:

... a dynamic network of agents interacting in a specific economic/industrial area under a particular institutional infrastructure and involved in the generation, diffusion and utilisation of technology (Carlsson and Stanckiewicz, 1991).

Once such a system is locked-in it is very difficult to displace it and alternative technologies can be locked-out for a long time even if they demonstrate improvements upon the established systems (Unruh, 2000). It is impossible to isolate a single factor, which could un-lock the system, but one possibility could be that the existing system loses viability because the selection environment is changing and provides new types of challenges which cannot be met with the dominant technology or require advances which are only possible at too high costs (Schot et al., 1994). When alternative technologies do meet the new challenges the process of building a new TSIS that is created around the new technology starts. In Jacobsson and Johnson (2000), the rise of renewable energy technologies are explained by analysing the development of a new TSIS that co-evolves with the development of a new technology.

The growth of an emerging TSIS can be stylised by identifying different development phases, such as a formative phase and a diffusion phase (Jacobsson and Bergek, 2004). The formative phase is characterised by a range of competing designs, small markets, many entrants and high uncertainty in terms of technologies, markets and regulations (Jacobsson and Johnson, 2002). This phase 
involves the exploration of niche markets where the technology can develop and be tested by users and demonstrate its superiority in some dimension(s), such as environmentally or economically (Kemp et al., 1998). The development phase is characterised by a fast growing market, a selection of a dominant design and a fast reduction in production costs. To unlock the existing energy system, it is important that several TSIS develop successfully and take over part of the existing energy system. An important research question is: what are the determining factors that explain this successful growth?

Edquist (Edquist, 2001) states that these determining factors can be traced by identifying all those activities that take place in innovation systems that influence the development, diffusion and use of an innovation. These activities are also called 'Functions of Innovation Systems'; from now on we will call them 'system functions'. The concept of system functions was developed by Jacobsson and Johnson (2000) who defined it as "a contribution of a component or a set of components to a system's performance". They argue that a TSIS, "may be described and analysed in terms of its 'functional pattern', i.e. in how these functions have been served" (Jacobsson and Johnson, 2000). The system functions are related to the character of, and the interaction between, the components of an innovation system, i.e. actors (e.g. firms and other organisations), networks and institutions, which may be specific to one innovation system or 'shared' between a number of different systems (Jacobsson and Johnson, 2000; Edquist, 2001). To understand how a technology is developed, diffused and implemented, the functional pattern of the related TSIS will be described and analysed through time. We expect that the more functions are served and the better they are served, the better the performance of the TSIS, thus the better the development, diffusion and implementation of innovations (Edquist, 2001). ${ }^{1}$ In the following paragraph, the system functions and how they have been measured will be described.

\subsection{System functions}

In recent literature different sets of system functions are used to structure empirical material. In Hekkert et al. (forthcoming), these sets of system functions have been discussed and one system functions list is proposed. We will use this set of system functions to structure the empirical work on biomass digestion.

\subsubsection{Function 1: entrepreneurial activities}

The existence of entrepreneurs in the innovation system is of prime importance. Without these entrepreneurs innovation would not take place and the innovation system would not even exist. Thus the entrepreneur is essential for

\footnotetext{
${ }^{1}$ See Chapter 3 Methodology for a more detailed description on how the functional pattern is described and how our manner differs from previous studies.
}

a well-performing system. The role of the entrepreneur is to turn the potential of new knowledge development, networks and markets into concrete actions to generate and take advantage of business opportunities. Entrepreneurs can be new entrants that see such opportunities in new markets or incumbent companies who diversify their business to take advantage of new developments. Our framework starts from the proposition that all seven system functions are important to reach a good system performance. However, when one would rank the different system functions, one might state that the functions two to seven are supportive in relation to function one; they should create the right entrepreneurial climate in which entrepreneurial activities can blossom. Note however, that it is the combination of the system functions that leads to system performance, not just entrepreneurial activities. This function can be analysed by mapping the number of new entrants, the number of diversification activities of incumbent actors and the number of experiments with the new technology (see Chapter Methodology for quantitative indicators).

\subsubsection{Function 2: knowledge development (learning)}

Mechanisms of learning are at the heart of any innovation process. For instance, according to Lundvall (1992) 'the most fundamental resource in the modern economy is knowledge and, accordingly, the most important process is learning'. This function includes 'Learning by Searching' and 'Learning by Doing'. We have mapped this function by counting the number of $R \& D$ projects per year.

\subsubsection{Function 3: knowledge diffusion through networks}

The network makes out the structure of the innovation system; it can be considered as an intermediate form of organisation between organisations and markets. According to Carlsson and Stanckiewicz (1991), its essential characteristic is the exchange of information. This is important in a strict $R \& D$ setting, but especially in a heterogeneous context where $\mathrm{R} \& \mathrm{D}$ researchers meet government, competitors and market. Networks allow policy decisions (standards, long-term targets) to be based on the latest technological insights and information through networks can lead to changing $R \& D$ agendas affected by changing norms and values. We mapped the number of workshops and conferences devoted to digestion. We used this indicator as a proxy for knowledge exchange in the digestion network.

\subsubsection{Function 4: guidance of the search}

Since resources are limited in nature, it is important that when various different technological options exist, specific foci are chosen for further investments. Without this selection there will be insufficient resources left over for the individual options. The function can be fulfilled by a variety of system components such as the industry, the government and/or the market. As a function, guidance of 
the search refers to those activities within the innovation system that can positively affect the visibility and clarity of specific wants among technology users. An example is the announcement of the government goal to aim for a certain percentage of renewable energy in a future year. This event grants a certain degree of legitimacy to the development of sustainable energy technologies and stimulates the allocation of resources for this development.

An important, though elusive, class of phenomena here concerns expectations (see the work of van Lente, 1998, 2000). Often actors are 'initially' driven by little more than a hunch. Vague ideas are often tried out and their success (and failure) can be communicated to other actors, thereby reducing the (perceived) degree of uncertainty. Occasionally, under the influence of 'success stories', expectations on a specific topic converge and generate a momentum for change in a specific direction.

This function can be evaluated by mapping specific targets set by governments or industries regarding the use of a specific technology and by mapping the number of articles in professional journals that raise expectations about new technological developments. By counting the number of articles that are positive or negative regarding the new technology development, the state of debate can be assessed. A strong discussion about the potential shortcomings of a new technology is likely to hamper further developments while a strong emphasis on the positive aspects is likely to stimulate technology development.

\subsubsection{Function 5: market formation}

A new technology often has difficulties to compete with embedded technologies, therefore it is important to create protected spaces for new technologies. One possibility is the formation of temporary niche markets (Schot et al., 1994) for specific applications of the technology. Another possibility is to create a temporary competitive advantage by favourable tax regimes or minimal consumption quotas.

By mapping the number of niche market initiatives, specific tax regimes for new technologies and environmental standards that improve the chances for new sustainable technology, the fulfilment of this function can be assessed.

\subsubsection{Function 6: resources mobilisation}

Resources, both financial and human capital, are necessary as a basic input to all the activities within the innovation system. For biomass digestion, the allocation of sufficient physical resources, in the shape of the biomass material or land to grow, store or process it, is also necessary to make further developments possible.

This function is difficult to analyse by specific indicators, since the information about whether resources are sufficiently available or not, can only be found from opinions of actors in the literature. We analysed this function by counting statements of actors in literature regarding their perception of resource availability.

\subsubsection{Function 7: support from advocacy coalitions}

In order to develop well, a new technology has to become part of an incumbent regime, or has to even overthrow it. Parties with vested interests will often oppose this force of 'creative destruction'. In that case, advocacy coalitions can function as a catalyst; they put a new technology on the agenda (function 3), lobby for resources (function 6), favourable tax regimes (function 5) and by doing so create legitimacy for a new 'technological trajectory' (Sabatier, 1988, 1998; Sabatier and Jenkinssmith, 1988). If successful, advocacy coalitions grow in size and influence and may become powerful enough to brisk up the spirit of creative destruction. The scale and success of these coalitions are directly dependent on the available resources (function 5) and the future expectations (function $3)$. We analysed this function by mapping the number of statements in literature by interest groups.

Finally, the system functions are not independent from each other but interact and influence each other. It is possible that the fulfilment of a certain function has effects on other functions. For instance, a certain amount of knowledge creation is necessary to create expectations for the new technology, which may lead to legitimacy. Therefore, we expect a non-linear causal model with multiple interactions between the system functions that will positively affect the performance of the system. The fact that system functions interact and influence each other can even be considered a necessity. The function fulfilment can lead to positive (virtuous) cycles of processes that strengthen each other and lead to the building up of momentum to create a process of creative destruction within the incumbent system (Jacobsson and Bergek, 2004). Therefore, empirical research should focus on providing insight on how the process of momentum building takes place. However, the same reversed process can also occur, if some system functions are not fulfilled, a negative (vicious) cycle is set off. On the basis of empirical data, the interaction between the functions and whether a positive or negative cycle takes place can be found in Section 5 'System Functioning'.

\section{Methodology}

\subsection{Historical event analysis}

In recent empirical work concerning system functions, generally qualitative analysis is used. This method strongly rests on the results from interviews. The set of system functions serves mainly as a way to structure empirical material, see (Andersson and Jacobsson, 2000; Jacobsson and Bergek, 2004). The downside of this method is that it is not possible to construct detailed patterns of function activities since interviews generally lead to information on a limited number of key-events. We propose to use as much quantitative indicators as possible in order to be able to map functional patterns over time (see description of System Functions). For this purpose we developed a 
method inspired by process analysis as deployed by Van de Ven and colleagues (Van de Ven et al., 1999; Poole et al., 2000). Stemming from organisational theory, their usual focus is on the firm and firm networks; in our case the analysis is deployed at system level. Basically, the approach consists of retrieving as many historical events related to a technological development as possible based on professional journals, newspapers and websites. The events are stored in a database, classified and systematically allocated to specific system functions. Functional patterns can then be extracted from the database. The methodology results in a coherent sequence of events and trends that describe how things change over time. In our case, the event sequence analysis is used to analyse the development, diffusion and implementation of biomass digestion in the Netherlands from 1974 to 2004.

The system functions are measured by counting instances of event types over time. All events are weighted the same, but through the historical description some relevant events are highlighted by naming them explicitly in the storyline. However, a distinction should be made regarding the nature of the contribution of an event to the fulfilment of a function. Some events have a negative contribution to the development of the technology, for instance an expression of disappointment, or the opposition of an important political group. These events are counted separately and are represented as negative scores. In a similar way the relation between events and positive cycles is established. The negative and positive scores are not added, since the difference between the negative and positive component depicts the debate that is going on (see Table 1 for the indicators of the system functions). At this time we are not able to make an absolute statement on whether a function is fulfilled well enough or not since we lack empirical and theoretical insights on the size of such a threshold. We therefore focus on the rise and fall of the number of activities over time and whether interactions between system functions take place.

The fulfilment of the system functions is represented in graphs. The positive line represents the total amount of positive activities per year and the negative line the sum of negative activities that occur per year for that particular function. The graphs are used to illustrate the development of the system functions throughout the examined time period and should not be interpreted as the absolute result/ answer of how the system functions have been fulfilled.

\subsection{Boundaries of this study}

This paper presents a chronological description of the events that have taken place in biomass digestion development in the Netherlands from 1974 to 2004. The analysis of biomass digestion is restricted to the digestion of manure, organic- and agricultural waste. Digestion of wastewater is not included since it involves a totally different innovation system with different actors and different institutions. Furthermore, the technological factors affecting the diffusion are not the same due to the difference in feedstock.

\subsection{Technical aspects of biomass digestion technology}

This paragraph will give an overview of the technical aspects of biomass digestion.

Anaerobic digestion is a low-temperature biochemical process, through which a combustible gas - biogas - can be produced from biomass feedstock. Biogas is a mixture of

Table 1

Indicators for measuring system functions

\begin{tabular}{|c|c|c|}
\hline Function & Indicator & Sign/value \\
\hline Function 1: entrepreneurial activities & $\begin{array}{l}\text { Project started } \\
\text { Project stopped }\end{array}$ & $\begin{array}{l}+1 \\
-1\end{array}$ \\
\hline Function 2: knowledge development & $\begin{array}{l}\text { R\&D projects, Investment in } R \& D \text {, desktop/assessment/feasibility studies on } \\
\text { digestion }\end{array}$ & +1 \\
\hline Function 3: knowledge diffusion & Workshops, conferences & +1 \\
\hline Function 4: guidance of the search & $\begin{array}{l}\text { Positive expectations on digestion } \\
\text { Regulations by government } \\
\text { Negative expectations on digestion } \\
\text { Expressed deficit of regulations }\end{array}$ & $\begin{array}{l}+1 \\
-1\end{array}$ \\
\hline Function 5: market formation & $\begin{array}{l}\text { Specific favourable tax regimes and environmental standards } \\
\text { Expressed lack of favourable tax regimes or favourable environmental } \\
\text { standards }\end{array}$ & $\begin{array}{l}+1 \\
-1\end{array}$ \\
\hline Function 6: resources mobilisation & $\begin{array}{l}\text { Subsidies, investments for digestion } \\
\text { Biomass streams allocated to project } \\
\text { Expressed lack of subsidies, investments } \\
\text { Shortage of biomass streams allocated to project }\end{array}$ & $\begin{array}{l}+1 \\
-1\end{array}$ \\
\hline Function 7: advocacy coalition & $\begin{array}{l}\text { Support by government, industry } \\
\text { Expressed lack of support by government, industry }\end{array}$ & $\begin{array}{l}+1 \\
-1\end{array}$ \\
\hline
\end{tabular}




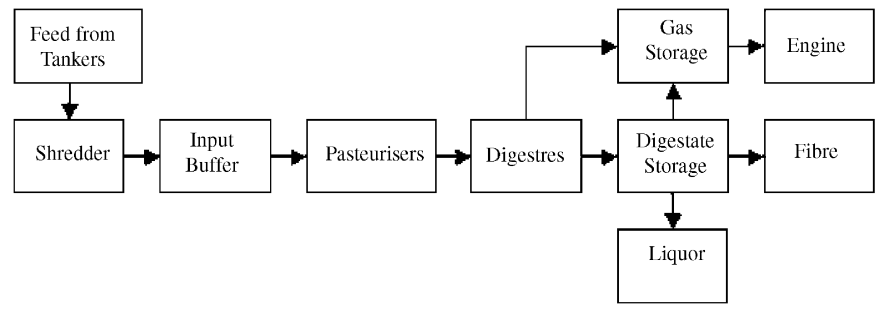

Fig. 1. Diagram of digestion process.

carbon dioxide $\left(\mathrm{CO}_{2}\right)$ and methane $\left(\mathrm{CH}_{4}\right)$, which can be used to generate heat and/or electricity via secondary conversion technologies like gas engines and turbines. High moisture biomass feedstock is especially well suited for the anaerobic digestion process.

The feedstock is placed into a digester, a warmed, sealed airless container. The digestion tank is continuously stirred and heated to create the ideal condition for biogas conversion. There are three types of temperature ranges where digestion can occur: psychophilic $\left(10-25^{\circ} \mathrm{C}\right)$, mesophilic $\left(25-35^{\circ} \mathrm{C}\right)$ and thermophilic $\left(49-60^{\circ} \mathrm{C}\right)$. However, most of the plants operate on the higher temperature (Raven, 2005). Although there is a constant inflow and outflow of material, the average retention time can vary from ten to 36 days, depending on the type of feedstock (Raven, 2005). This allows a significant percentage of the organic solids to be converted to biogas. The outflow of the digesters can be in two forms: biogas and a liquor/fibre mixture, known as 'digestate'. The gas from the digesters is stored to control the flow into the engine and this engine is used to generate heat and electricity for on-site or off-site use (see Fig. 1-diagram of digestion process).

\section{Event description and system function fulfilment}

In this section, a chronological description of the events that took place in the biomass digestion trajectory is presented. The description will be subdivided into different year periods. The end of each period is chosen on the basis of change in activities or key events, therefore not all periods are equal in length.

\subsection{The pioneers era, 1974-1987}

The beginning of this period is characterised by pioneers setting up the first experiments on manure digestion, due to high and increasing energy prices as a result of the oil crises in the previous decades. Digestion of manure seems a promising option to convert a waste product (manure) into useful energy. Several farmers are enthusiastic about this option and digestion installations are set up on several farms (Verbong et al., 2001). Developers of digestion equipment, such as Paques, see a great market opportunity to install digestion equipment on farms. As a result the number of digestion plants on farms increases between 1979 and 1983, and consequently the application of digestion moves from laboratory scale to practical scale
(Nes, 1988). However, a survey on the functioning of the digestion plants built on farms shows that there are many technical and economical problems. Nonetheless, it is believed that the problems are solvable and so the 'Netherlands Ministry of the Environment' (VROM) constructs a trial plant in Assendelft within the framework of the "National Research Programme for Recycling of Waste" (NOH programme) (Nes, 1988). However, shortly after its construction the plant is shut down, due to the decrease of conventional energy prices resulting in a lack of profits, technical problems and complicated permit regulations (Nes, 1988; Verbong et al., 2001).

Here, the lack of supporting policies forms a barrier, in addition to the technical and economic problems. The government shows a lack of vision and strategy regarding the development and introduction of renewable energies in general, be it on short- or long-term, small- or large-scale, centralised or decentralised energy projects. For digestion the situation is even worse, since digestion is not seen as a key renewable energy technology that will contribute to the national energy supply like biomass combustion (Blok, 1985).

Around 1985 the manure surplus in The Netherlands becomes an urgent problem. Several strategies to solve the problem are explored. One solution is to convert very wet manure streams into dry fertiliser that can easily be exported or transported to other parts in The Netherlands where there is a manure shortage. Digestion is seen as a means to reduce the energy demand of these manure conversion plants. The government support for manure digestion is from that moment only framed in the context of the manure problem and not in terms of its potential contribution to renewable energy. This is perceived as a great disappointment by the renewable energy lobby (Blok, 1985; Verbong et al., 2001). In addition to technical problems and the lack of supportive policy there is a drastic drop of oil prices in 1986 resulting in decreasing profits for biomass digestion (Lysen et al., 1992). Additionally Minister Braks of Agriculture announces in 1986 that no more money and support will be given to the further development of manure digestion nor to already existing projects, due to the technical problems and the reduced fossil fuel energy prices, resulting that digestion becomes expensive and unprofitable (Nes, 1988). The result is that by the end of this period hardly any activities occur around the development or diffusion of biomass digestion technology. Clearly, the guidance of search is not in favour of digestion.

\subsection{Impulses and inconsistency around digestion, 1988-1995}

Nonetheless the discontinuity of activities in the previous years, some activities are picked up again. In 1986, the community Deersum, Friesland has some plans to build a central manure digestion plant in combination with a wind turbine, which provides the village with electricity and 
makes it self-sustained. The wind turbine is in operation in August 1987 and the digestion plant at the beginning of 1988. The first year is used for experimentation and collecting performance data. For the digestion plant several start-up problems occur: congestion of the manure pumps, high content of hydrogen sulphide $\left(\mathrm{H}_{2} \mathrm{~S}\right)$ and low electricity production of the combined heat and power (CHP) plant. Most of the problems are solved, however the costs for this installation remain high (Nes, 1989). The plant closes in 1994 due to technical problems and a poor economic performance.

Another centralised plant, the largest ever built in the Netherlands, is set up around 1987 in the southern Netherlands, Helmond, by the first manure-export venture, Promest B.V. (Henley, 1991). The aim is to convert 600,000 ton manure $(15 \%$ of the Dutch pig manure) into 75,000 ton manure-grains, which are exported to Spain and Portugal (Didde, 2004). However, several technical problems, such as corrosion problems and foam formation, hamper a smooth and full capacity running of the plant (Raven, 2005). Finally, the plant is closed down in late 1994, since the supply of manure remains too expensive and the technology is not robust enough (Henley, 1991; Holm-Nielsen and Al Seadi, 1998a, b; Didde, 2004).

In 1988, digestion comes on the political agenda due to the expectations that much biomass waste will become available in The Netherlands. Due to land filling capacity problems, plans are made to stimulate households to separate organic waste from other waste. These organic waste flows are to be converted into compost, which can be used in agriculture and households as organic fertiliser to improve soil quality. The traditional conversion method for organic waste is aerobic fermentation (composting), which does not produce energy, but the large organic waste flows also feed the idea that it can be used as sustainable energy resource by means of digestion (Nes, 1988).

In 1989, the Ministry of EZ, VROM and NOVEM commission a programme called 'Energy production from waste and biomass' (EWAB) with the aim to promote the use of waste and biomass as energy source. Within the framework of the EWAB and NOH programme several research, evaluation, feasibility and comparative studies of several plants are carried out and platforms are set up for biomass digestion (NOVEM, 1992; Haskoning, 1992a, b; E\&Mspectrum, 1993a).

In 1990, researchers at the University of Wageningen and engineering consultant Heidemij, set up a plant using the Biocel conversion system and another two plants are set up in Lelystad and Tilburg (Haskoning, 1991; E\&MT, 1991). These latter two plants are supported by the Ministry of VROM to make digestion the spearhead within the programme ' $\mathrm{CO}_{2}$-emission reduction via waste regulation' of Senter ${ }^{2}$ (Brinkmann, 2000).

\footnotetext{
${ }^{2}$ Senter is a financing agency under the Dutch Ministry of Economic Affairs.
}

Another plant is built in 1993 called 'Greenery' in Breda, where the leftovers of the fruit and vegetable auction are digested (Zoeten et al., 1992).

In this same year, a decree on the "quality and use of organic manure/fertilisers' (Besluit Kwaliteit en Gebruik Overige Organische Meststoffen, BOOM) is introduced which determines the quality and composition of a nonmanure organic-based fertiliser. The aim of this regulation is to build trust in the quality and purity of organic waste compost in order to stimulate demand (MilieuMagazine, 2001; Reumerman, 2004).

In 1994, the already expected large-scale collection and separation of organic waste is introduced in the Netherlands (Brinkmann, 2000). Therefore, the feedstock part is well taken care of for digestion. However, in October 1994 the Ministry of EZ announces a cut back of 81 million euro from the R\&D, demonstration and application budget for new energy technologies (Vos, 1994). The cut of the budget forms a real threat to the research, development and market introduction of renewable energies in general, since they are not profitable without subsidies yet. The EWAB programme budget is reduced from 3.6 million euro to 2.5 million euros. Research institutes such as the Energy Research Centre of the Netherlands (ECN) and the Netherlands Organisation for Applied Scientific Research (TNO) suffer most from the R\&D cut backs. On top of the misery for the entire sustainable energy sector, the problems for digestion are even worse since the Ministry of Economic Affairs announces that only biomass combustion and gasification are supported but not digestion. The consequences are seen shortly after when the combined digestion plant and wind turbine in Deersum, Friesland is shut down, due to technical problems and the political unwillingness to further support digestion (DE, 1994).

The sustainable energy lobby complains that biomass digestion is not seen as a promising technology for largescale energy supply and the fact that farmers are not stimulated enough to use manure for manure digestion, instead of just spreading it on the land (Daey Ouwens, 1993). In several publications biogas production is predicted to be only profitable if there are more subsidies allocated to digestion and the fossil energy prices are high (Daey Ouwens, 1993; E\&Mspectrum, 1993b; Vos, 1994).

A potential solution for digestion is the so-called codigestion technology. This implies that organic waste is added to the manure in order to produce much higher quantities of biogas. This would lead to much better returns on investments. However, in the Netherlands codigestion is not feasible since it is unclear which types of organic waste flows can be mixed with the manure. This is a problem since the quality requirements of the produced digestate are very strict and farmers do not know how different organic additives to the manure influence the final digestate quality. In neighbouring countries lists with substances that are allowed are available, leading to many co-digestion initiatives (Raven, 2005). A lobby starts asking the government to come up with a list of allowed 
organic substances but it takes until 2004 before this is finally published (Haskoning, 1993). A prime reason for this delay is the already existing manure surplus in The Netherlands, resulting that policy makers are not eager to increase the total manure flow by adding organic waste to manure in digestion plants (MilieuMagazine, 2001).

\subsection{The rollercoaster continued, 1995-2004}

This period is marked by the closure of several plants set up in previous years. The organic waste digesters have a hard time due to several reasons. First, it proves to be technically very difficult to digest organic waste flows from households since it contains much woody material (from thinning). Second, the composting of waste proves to be much cheaper then digestion, leading to the situation that composting plants are more successful in organising sufficient feedstock from the market. Finally, it is problematic to find enough end-uses for the digestate (Janse, 1996a, b; Abbas, 1998). As a result the plants constructed in Helmond, Breda and Tilburg are shut down (Janse, 1998).

Furthermore, a general political uncertainty overshadows this period, since the government formulates no common and consistent regulations. For instance, the Ministry of Economic Affairs publishes the 'Third White Paper on Energy' ${ }^{3}$ (Derde Energie Nota) but doesn't provide any common strategy on the technical and economical development of bio-energy on how to achieve the goals of the White Paper (EZ, 1995). From a benchmarking study it appears that the size of investments and the number of policies in the Netherlands is very broad and the technical potential is still small, resulting in high costs (E\&Mspectrum, 1998). This triggers several actors to unify the scattered initiatives of the pioneers by setting up platforms and information centres and to build a coalition to counter the critical voices that do not see biomass digestion as a promising technology (NOVEM, 1998). Furthermore by 'joining forces' they hope to obtain an exemption from the 'regulating energy tax' (REB) for electricity produced from biogas (DE, 2000). ${ }^{4}$

Since the organic waste digesters are not successful, in 1999 a different concept is tried out. It leads to the construction of the largest digestion plant for organic waste in Groningen build by VAGRON. The plant is a demonstration plant for on site separation of integral household waste into different fractions, where the 'organic wet fraction' is digested and the rest of the integral waste is incinerated. The biogas produced is used to increase the electrical efficiency of the waste incinerator (DE, 1999; ECN, 1999; Stromen, 1999; Vermaat, 1999).

\footnotetext{
${ }^{3}$ The aim is to achieve a $10 \%$ share of renewable energies in 2020 where biomass should contribute $44 \%$ (EZ, 1995).

${ }^{4}$ In The Netherlands conventional electricity is taxed with REB, whereas renewable electricity is not. This should reduce the gap in production price, however a lobby was necessary to argue that manure and organic waste should be seen as a renewable energy source as well.
}

Even though the circumstances for manure digestion have not changed, pioneers and idealists supported by Academia and the Dutch platform for Sustainable Energy keep developing initiatives. This leads to three demonstration centres for digestion of manure on farms, 'Nij Bosma Zathe Goutun', 'Sterksel' and 'De Marke' (DE, 2002a; ECOFYS, 2003; Stromen, 2003).

Nonetheless, the impulses and efforts to establish digestion as a solution for several problems, i.e. manure surplus, waste treatment and climate change, the development and application of digestion is still delayed due to inconsistent policies and regulations. There is a call for the government to provide more financial security, facilitate the permit application procedures and provide a level playing field (DE, 2002b). Additionally, since the election in 1998 it is not clear which direction the government will take with respect to financial support, such as the energy tax, since such regulations are still very important for the development of digestion to become a self-sustained technology (DE, 2002c). An example of financial and political uncertainty is the delayed introduction of the 'Environmental Quality Electricity Production' (MEP) regulation. This regulation subsidises the electricity production of renewable energy for 10 years, by which the - till then rather low-economic performance of most biomass technologies is improved (EZ, 2003). Therefore the Dutch Agency for Renewable Energies (PDE) lobbies to qualify all forms of digestion, except from dump gas and waste water treatment installation, for the MEP (DE, 2003b).

The year 2004 seems to be the crucial year for manure digestion. Finally, after long years of struggling the regulations for co-digestion are altered. Minister Van Geel (VROM) and Minister Veerman (LNV) revise the complicated regulations and policies around manure digestion and farmers are finally allowed to add some organic material to the digestion of manure. Further, the Ministries will develop a list of organic substances that will allow codigestion. In addition clear directives will be developed for the set-up and testing of environmental permits (Stromen, 2004a; Wijland, 2004). Due to this 'green list' and simplified permit procedure, experts expect an increase of biogas plants on farms. However, the real breakthrough for dozens of large biogas plants is expected to be achieved only if the government releases the second half of the 'green list', where also products from the food industry, such as frying fat and swill will be included (TW, 2004; Zoethout, 2004; Stromen, 2004c). Finally, there is enough feedstock available for digestion and some improvements are made for the output of digesters. Digestion and production of biogas is recognised as a sustainable energy technology and an MEP subsidy of 9.7 euro cent $/ \mathrm{kWh}$ is granted for a period of 10 years.

However, since a plant has an estimated pay-off period of 6-9 years, only a period of profit of $1-4$ years is then available, which can be considered as too short. Therefore, a lobby continues for a longer MEP subsidy to make the return on investments more interesting, however the 
financial climate for digestion has never been as positive as today (DE, 2003a, b; Stromen, 2004b). This results in many initiatives to put digestion on agricultural agenda like symposia and workshops (Stromen, 2003; Stromen, 2004a-c). Still, the future needs to shed light whether the change in legislation is powerful enough to create many entrepreneurial activities leading to a large diffusion of digestion in The Netherlands.

Finally, to sum up the whole period of 30 years, it can be said that the development of biomass digestion has been very sporadic and fluctuated substantially. There have been a lot of political and financial uncertainties, due to changing governments and unanimity between the Ministries on biomass digestion. There has been no continuity and stability in government regulations longer than a few years, as to allow an increase in activities around biomass digestion. Biomass digestion was always only seen as a temporary solution to several current problems but never as long-term alternative, i.e. reduce manure surplus in the 1980s, waste surplus and $\mathrm{CO}_{2}$ emissions in the 1990s, because in the end other technologies, such as combustion or composting were preferred. However, in 2003-2004 the regulations for co-digestion are finally altered, which might bring along the long awaited breakthrough for digestion technology.

\section{System functioning}

In this section, we will answer the research question 'how can we explain the low diffusion of digestion in the Netherlands?' by means of analysing the functional pattern of the digestion innovation system.

At the beginning of the period 1974-1987, pioneers develop entrepreneurial activities (Fig. 2) and some knowledge is created (Fig. 3). The actions are not strongly coordinated and a lobby for better institutional arrangements

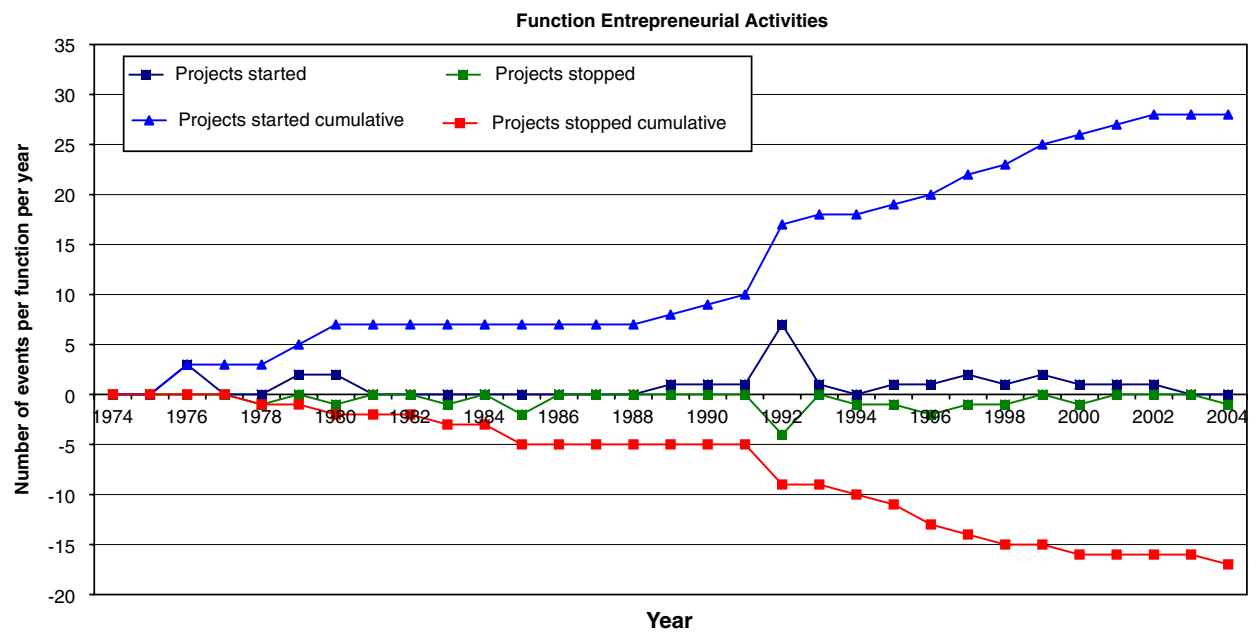

Fig. 2. Activity pattern for Function 1: entrepreneurial activities.

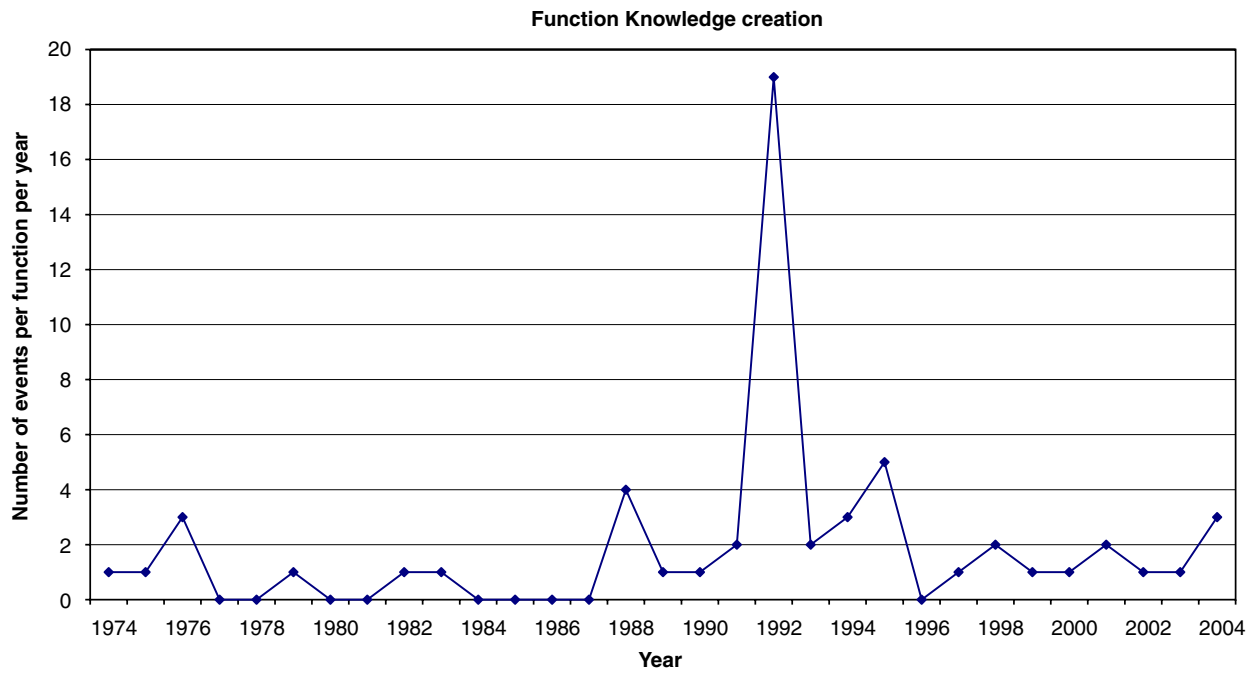

Fig. 3. Activity pattern for Function 2: knowledge creation. 
is lacking since only a very limited number of activities can be classified as advocacy coalitions (Fig. 7). This first period is also characterised by a lack of activities in terms of system functions such as guidance (see very low number of positive guidance activities in Fig. 5), market formation and resource allocation (see the complete lack of resource mobilisation in this period in Fig. 6). Thus, the initial experiments fail to lead to the build up of other system functions that are needed to propel this emerging technology. The consequence is that after technological disappointments no continuation of activities takes place (see the negative lines in Fig. 2 that represent the projects stopped between 1978 and 1985; see Fig. 5 negative lines in 1983, 1985 and 1986). This results in a temporary stop of activities, and hardly anymore functions are fulfilled.

Between 1989 and 1994 an impulse for biomass digestion occurs, due to the compulsory collection of organic waste, which is an interesting resource for biomass digestion, so that it is rediscovered as promising technology. Now we see a boost of research activities due to government programs (see peak in Fig. 3). This is accompanied by knowledge diffusion activities (see peak in 1992 in Fig. 4). We also observe the construction of several plants (see increase in positive cumulative line in Fig. 2 since 1988). However, even though the government gets involved in stimulating knowledge development, this does not lead to acceleration in the construction of digestion projects (this can be seen in the cumulative negative line in Fig. 2 that depicts the closing of digestion plants). An explanation that acceleration does not take place can be found in the functions guidance of the search (Fig. 5) and resources mobilisation (Fig. 6). Fig. 5 does not show a strong increase in positive guidance activities; In fact, every positive statement seems to be alternated by negative statements. This underpins our empirical story in which we show that digestion was never seen as a key technology

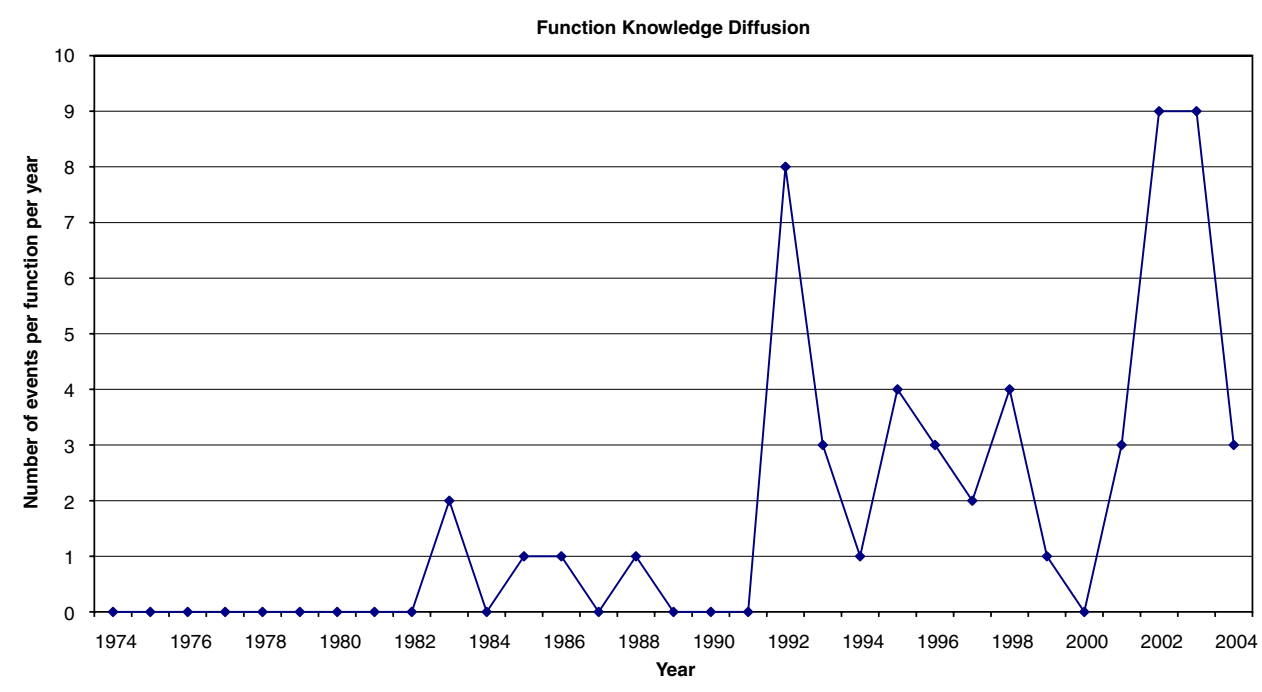

Fig. 4. Activity pattern for Function 3: knowledge diffusion.

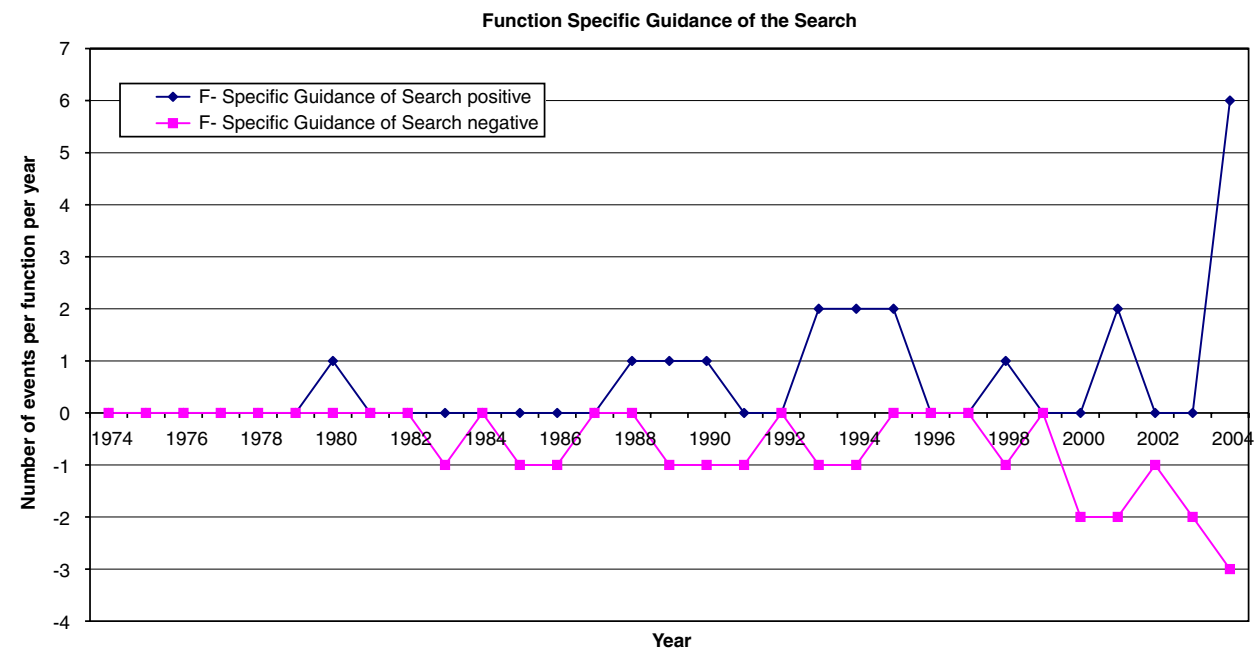

Fig. 5. Activity pattern for Function 4: guidance of the search. 


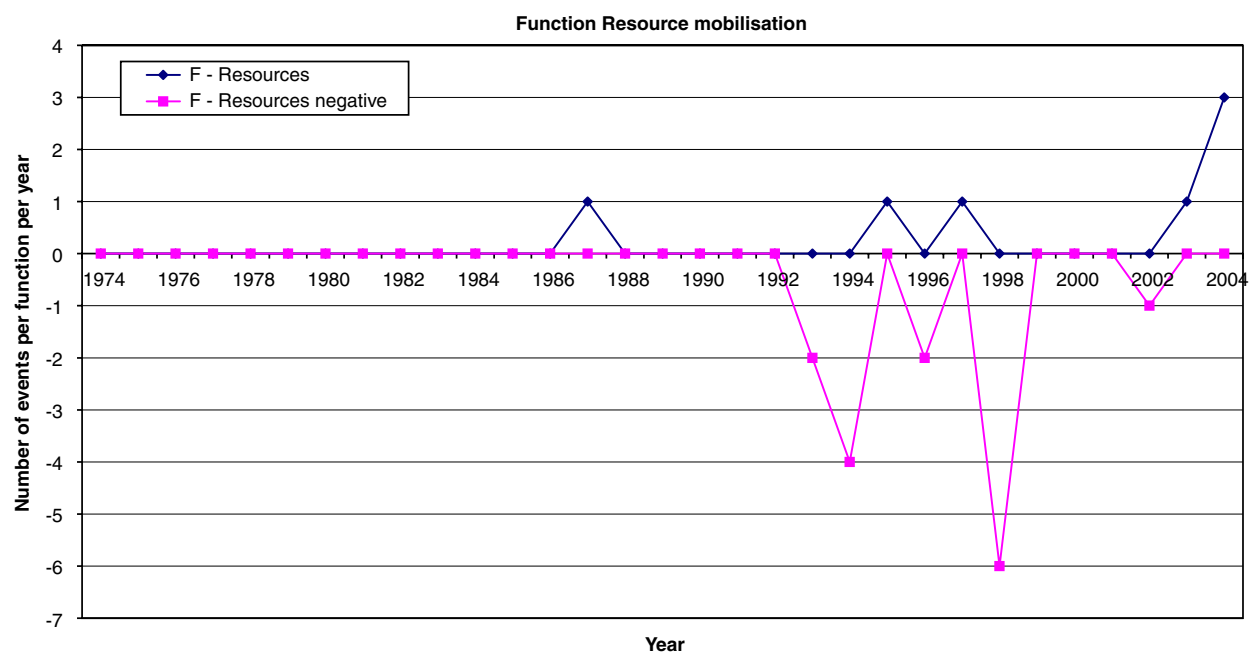

Fig. 6. Activity pattern for Function 6: resource mobilisation.

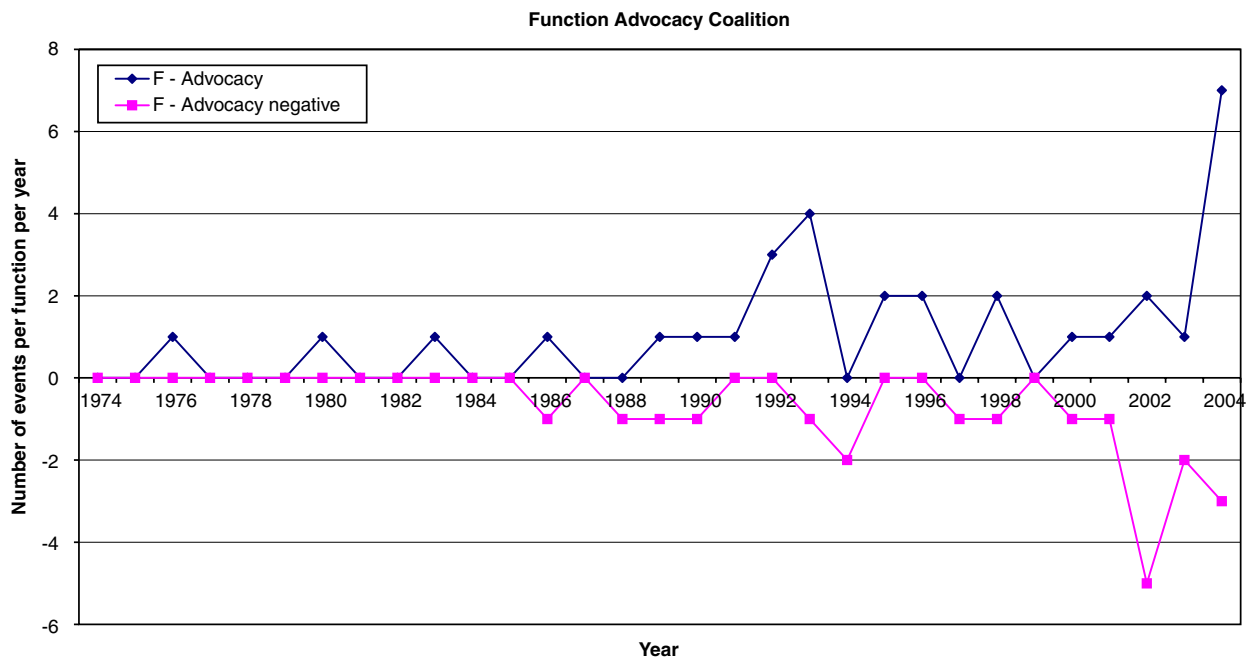

Fig. 7. Activity pattern for Function 7: advocacy coalitions.

in terms of renewable energy and that the government has been openly quite negative about this technology. Fig. 6 shows that during this period actors complain regularly about the lack of financial support for this technology.

The final period 1995-2004 is marked again by the incoherent guidance of the government and a shortage of financial resources (see Figs. 5 and 6). In addition there are still severe technological problems and as a result, most of the plants are shut down (see Fig. 2). Finally, a lobby for better circumstances for digestion picks up (see peak in Fig. 7 in 2004). This will have most likely contributed to the very important changes such as favourable regulations that make co-digestion possible and a much better financial situation due to decent feed-in tariffs for biogas based electricity. This again gives new impulses to the biogas scene and a general increase of activities from 2002 onwards is observed and a further increase in activities is likely to take place in the coming years.

\section{Conclusions}

How can we explain the slow diffusion of biomass digestion in the Netherlands? The dynamic analysis of the functioning of the biomass digestion innovation system shows problematic functional patterns. Not one of the system functions that were analysed showed a continuous build up over the years. We regularly see short periods of entrepreneurial activities by enthusiastic pioneers but this does not lead to positive feedbacks with other system functions. Thus, the system never gains enough critical mass to overcome the technological problems. Furthermore, the institutional environment in which this innovation system needs to function is unstable and very often not stimulating for digestion initiatives. In turn the biomass digestion community is often unable to successfully lobby for improved institutional arrangements. We do not observe many network and lobby activities, neither many joint initiatives between academia, research institutes and 
local projects. It seems that the promise and expectations around digestion technology are not able to mobilise a persistent group of actors that push forward this technology, also in difficult times. On the other hand, it is understandable that it is difficult to form a strong digestion network when the institutional framework is strongly fluctuating over the years, creating much uncertainty and is only sporadically in favour of digestion. Thus, what we see is a misalignment between government actions and the needs of entrepreneurs.

Policy lessons for an improved development and diffusion of biomass digestion follow directly from the above. Government policy should have focused on strengthening three system functions: guidance of the search, market formation and resources mobilisation. Specifically, this involves long-term, clear and supportive arrangements concerning the economics of biomass digestion plants, e.g. fixed feed-in tariffs for the electricity produced. This creates a market for digestion and due to the long-term character it guides entrepreneurs in their choice for this technology. Furthermore, supportive regulations regarding co-digestion (especially allowing carbon rich feedstock) would have greatly affected the developments. This would greatly influence the economics of digestion plants and resolve many uncertainties. We expect that by removing these two bottlenecks the biomass digestion community will grow and start fulfilling the other system functions that are necessary for biomass digestion development and diffusion.

How useful is the functional analysis of emerging innovation systems? Does it lead to additional insights compared to the empirical analysis?

First, the system function concept was very helpful in structuring the vast amount of empirical material and in analysing the empirical findings in a structured and coherent way. It helped to categorise different types of events that took place and to look for what the consequeces of certain events are on other events.

Second, the description of activities provided additional insights compared to earlier empirical studies. In Raven (2004), the importance of structural factors like changes in the socio-technical landscape (e.g. change in oil prices) and a mismatch in rule sets (e.g. lack of co-digestion regulation) are highlighted. Also in our empirical work we highlight the same structural factors. However, on top of this the functional analysis shows the effect of these structural factors on the activities in the system and we show that these structural factors are in turn influenced by a lack of coordinated activities in the digestion innovation system. Hereby we get more understanding of the interplay between structural change of the institutional structure and the activities in the innovation system.

Finally, the fact that we analysed this troublesome story in terms of system functions, allows us to compare this case with more successful developments. In this way we can learn how functional patterns differ in troublesome and successful processes of technological change and study the difference in interplay between institutional framework and innovation system activities. This is useful information when the aim of policy making is to contribute to well functioning sustainable energy innovation systems.

\section{Acknowledgements}

The authors are very thankful to Andre Faaij (Utrecht University), Thijs Oorthuys (Grontmij Nederland bv), Patrick Reumerman (BTG biomass technology group B.V.), Rob Raven (TUE), Bo Carlsson, (Case Western Reserve University), and Staffan Jacobsson (Chalmers University of Technology) for comments on (earlier versions of) this paper. Finally we would also like to thank the Knowledge Network for System Innovations and Transitions (KSI) and the Netherlands Organisation for Scientific Research (NWO) for financial support.

\section{References}

Abbas, D., 1998. Concurrentie of samenwerking? Duurzame Energie 8, $10-11$.

Abbot, A., 1995. Sequence analysis: new methods for old ideas. Annual Review of Sociology 21, 93-113.

Andersson, B.A., Jacobsson, S., 2000. Monitoring and assessing technology choice: the case of solar cells. Energy Policy 28 (14), 1037-1049.

Blok, K., 1985. Overheid drukt duurzame energie niet door. Duurzame Energie (3), 4-5.

Brinkmann, A.J.F., 2000. Vergisting van vast afval: praktijkervaringen en perspectieven in de nederlandse context. Symposium Biomassa: verbranden, vergassen, vergisten, pyrolyse Vereniging van Milieukundigen, Utrecht, 24 mei 2000, werkzaam bij Grontmij Water \& Reststoffen.

Carlsson, B., Stanckiewicz, R., 1991. On the nature, function and composition of technological systems. Journal of Evolutionary Economics (1), 93-118.

Daey Ouwens, C., 1993. Wordt biomassa belangrijkste energiebron? Duurzame Energie 12 (6), 10-13.

DE, 1994. Novem en ECN zullen zware klappen oplopen. Duurzame Energie 9, 8.

DE, 1999. Groningen krijgt grootste vergistingsinstallatie ter wereld. Duurzame Energie 5, 40.

DE, 2000. Classificatiesysteem in de maak. Duurzame Energie 2, 37.

DE, 2002a. Melkveebedrijf De Marke test installatie biomassavergisting. Duurzame Energie 38.

DE, 2002b. Overheid moet zekerheid en prikkels geven-workshop platform bio-energie. Duurzame Energie 2, 39.

DE, 2002c. Melkveebedrijf De Marke test installatie biomassavergisting. Duurzame Energie 8, 38.

DE, 2003a. Essent woedend over uitstel MEP. Duurzame Energie 4, 35.

DE, 2003b. Stel tarieven MEP ten minste drie jaar van tevoren vast. Duurzame Energie 5, 41.

Didde, R., 2004. Mestoverschot: ouderwets innoveren met poep - nieuwe wet kan verwerking eindelijk rendabel maken. Volkskrant 5.

E\&MSpectrum, 1993a. Technieken gft-verwerking op een rijtje. Energieen Milieuspectrum (8), 14.

E\&MSpectrum, 1993b. Biogas uit mest is geen kip met gouden eieren. Energie- en Milieuspectrum 1, 10.

E\&MSpectrum, 1998. Nederlandse beleid duurzame energie ambitious en duur. Energie- en Milieuspectrum 9, 5.

E\&MT, 1991. Biogas van GFT-vergister samen met stortgas opgewerkt in Tilburg. Energie and Milieutechnologie 12 (11/12), 10-11. 
ECN, 1999. Energie Verslag Nederland 1999, Uitvoeringsnota Klimaatbeleid, Deel I: Binnelandse Maatregelen.

ECOFYS, 2003. Bio-energie van eigen bodem. In: Opdracht van NOVEM.

Edquist, C., 2001. The Systems of Innovation Approach and Innovation Policy: An Account of the State of the Art. DRUID, Aalborg.

EZ, 1995. Derde Energie Nota-Duurzame energie. Ministerie van Economische Zaken, Den Haag.

EZ, M., 2003. Actieplan Biomassa: Samen werken aan bio-energie.

Foxon, T.J., Gross, R., Chase, A., Howes, J., Arnall, A., Anderson, D., 2005. UK innovation systems for new and renewable energy technologies: drivers, barriers and systems failures. Energy Policy 33 (16), 2123-2137.

Haskoning, 1991. Conversietechnieken voor GFT-afval. Nationaal Onderzoekprogramma Hergebruik van Afvalstoffen, NOH. N. a. RIVM, Haskoning Ingenieurs bureau.

Haskoning, 1992a. Grootschalige scheiding en vergisting van huishoudekijk en bedrijfsafval. In: Opdracht van Provinciaal Afvalverweijderingsbedrijf Zuid-Holland N.V. (PROAV).

Haskoning, 1992b. Onderzoek naar scheiding en vergisting van afval in Zuid-Oost Nederland. In: Het Kader van EWAB, in Opdracht van NV Afvalverbranding Zuid-Nederland (AZN) en gesubsideerd van NOVEM.

Haskoning, 1993. Conversietechnieken voor GFT-afval—Ontwikkelingen in 1992. In: Het Kader van Nationaal Onderzoekprogramma Hergebruik van Afvalstoffen beheer en coordinatie bij NOVEM and RIVM.

Hekkert, M.P., Suurs, R.A.A., Negro, S.O., Kuhlmann, S., Smits, R.E.H.M. Functions of innovation systems: a new approach for analysing technological change. Technological Forecasting and Social Change, forthcoming.

Henley, S., 1991. New Dutch muchrakers aim to make profit, not pollution. International Herald Tribune.

Holm-Nielsen, J.B., Al Seadi, T., 1998a. BIOGAS IN EUROPE-a general overview. Community-based Development of BioenergyExperiences from Ireland and the EU, Brú Ború, Cashel, Co. Tipperary, Ireland, South Jutland University Centre, Bioenergy Department, Denmark.

Holm-Nielsen, J.B., Al Seadi, T., 1998b. Biogas in Europe-A General Overview. Altener Event: Energy from Waste and Biomass. Tallinn, Estonia, South Jutland University Centre, Bioenergy Department, Denmark

Hoogwijk, M., 2004. On the global and regional potential of renewable energy sources. Chemistry. Utrecht, UU.

Hughes, T.P., 1983. Networks of Power: Electrification in Western Society, 1880-1930. The Johns Hopkins University Press, Baltimore.

Jacobsson, S., Bergek, A., 2004. Transforming the energy sector: the evolution of technological systems in renewable energy technology. Industrial and Corporate Change 13 (5), 815-849.

Jacobsson, S., Johnson, A., 2000. The diffusion of renewable energy technology: an analytical framework and key issues for research. Energy Policy 28 (9), 625-640.

Jacobsson, S., Johnson, A., 2001. The Emergence of a Growth Industry: A Comparative Analysis of the German, Dutch and Swedisch Wind Turbine Industries. Transformation and Development: Schumpeterian Perspectives (provisional title). S. C. Metcalf, U. Heidelberg, Physica/ Springer.

Jacobsson, S., Johnson, A., 2002. Transforming the Energy Sector: The Evolution of Technological Systems in Renewable Energy Technology. IMIT and Department of Industrial Dynamics, Gothenburg.

Janse, F., 1996a. Gestage groei biomassaprojecten. Duurzame Energie 3 (6), 9.

Janse, F., 1996b. GFT-vergistingsproject struikelt over voldoende aanvoer. Duurzame Energie 3 (6), 12.

Janse, F., 1998. Prijs biomassa remt ontwikkelingen. Duurzame Energie 8, 12.

Johnson, A., Jacobsson, S., 2001. Inducement and blocking mechanisms in the development of a new industry: the case of renewable energy technology in Sweden. In: Coombs, R., Green, K., Richards, A., Walsh, V. (Eds.), Technology and the Market. Demand, Users and Innovation. Edwar Elgar Publishing Ltd., Cheltenham, pp. 89-111.

Kemp, R., Schot, J., Hoogma, R., 1998. Regime shifts to sustainability through processes of niche formation: the approach of strategic niche management. Technology Analysis and Strategic Management 10 (2), 175-195.

Lundvall, B.-A., 1992. Introduction: National Systems of Innovation toward a Theory of Innovation and Interactive Learning. Pinter, London, pp. 1-19.

Lysen, E.H., Daey Ouwens, C., Onna, v.M.J.G., Blok, K., Okken, P.A., Goudriaan, J., 1992. De haalbaarheid van de produktie van biomassa voor de Nederlandse Energiehuishouding. EWAB. NOVEM.

MilieuMagazine, 2001. Vergisten geniet de voorkeur. Vakblad voor Milieumanagement 12 (12), 18.

Nes, W.J., 1988. Doorgaan met mestvergisting. Duurzame Energie 2, $27-29$.

Nes, W.J., 1989. Wind en biogas leveren Deersum helft stroom. Duurzame Energie 11 (5), 40-42.

NOVEM, 1992. Evaluatie van geintegreerd vergisten en verbranden van afval. In het kader van Energiewinning uit Afval en Biomassa.

NOVEM, 1998. Lopende projecten. BioVisie 9, 19.

Poole, M.S., van de Ven, A.H., Dooley, K., Holmes, M.E., 2000. Organizational Change and Innovation Processes, Theories and Methods for Research.

Raven, R., 2005. Strategic Niche Management for Biomass-A Comparative Study on the Experimental Introduction of Bioenergy Technologies in the Netherlands and Denmark. Sustainable Studies and Technology. Einhoven University of Technology, Einhoven.

Raven, R.P.J.M., 2004. Implementation of manure digestion and cocombustion in the Dutch electricity regime: a multi-level analysis of market implementation in the Netherlands. Energy Policy 32 (1), 29-39.

Reumerman, P., 2004. Personal Communication: Senior Consultant, BTG biomass technology group B.V.

Sabatier, P.A., 1988. An advocacy coalition framework of policy change and the role of policy-oriented learning therein. Policy Sciences 21 (2-3), 129-168.

Sabatier, P.A., 1998. The advocacy coalition framework: revisions and relevance for Europe. Journal of European Public Policy 5 (1), 98-130.

Sabatier, P.A., Jenkinssmith, H.C., 1988. Policy change and policy oriented learning - exploring an advocacy coalition frameworkintroduction. Policy Sciences 21 (2-3), 123-127.

Sagar, A.D., Holdren, J.P., 2002. Assessing the global energy innovation system: some key issues. Energy Policy 30, 456-469.

Schot, J., Hoogma, R., Elzen, B., 1994. Strategies for shifting technological systems - the case of automobile system. Futures 26 (10), 1060-1076.

Stromen, 1999. Nieuwe installatie maakt gft tot brandstof. Stromen 1 (13).

Stromen, 2003. Symposium 'Mestvergisting: winst voor boer en klimaat'. Stromen 5, 9.

Stromen, 2004a. VROM en LNV: eenvoudige regels voor mestvergisting. Stromen 1 (1), 7.

Stromen, 2004b. Biogas voor boeren eindelijk aantrekkelijk. Stromen 10 (6), 4

Stromen, 2004c. Tot vier keer hogere methaanopbrengst haalbaar: Nieuwe kans voor vergisting. Stromen 19 (11), 4.

TW, 2004. Vergisting hapert. Technisch Weekblad 35 (47), 15.

Unruh, G.C., 2000. Understanding carbon lock-in. Energy Policy 28 (12), $817-830$.

Unruh, G.C., 2002. Escaping carbon lock-in. Energy Policy 30 (4), 317-325.

van de Ven, A.H., Polley, D.E., Garud, R., Venkataraman, S., 1999. The Innovation Journey, Oxford University Press, Oxford.

Van Lente, H., 2000. In: Nik Brown, B. R. a. A. W. (Eds.), Forceful Futures: From Promise to Requirement. Contested Futures. A Sociology of Prospective Techno-science. Ashgate Publishing Company, London, pp. 43-64. 
Van Lente, H., Rip, A., 1998. In: Meulen, C. D. B. v. d. (Ed.), Expectations in Technological Developments: An Example of Prospective Structures to be Filled by Agency. Getting New Technologies Together. Studies in Making Sociotechnical Order. Walter de Gruyter, New York, pp. 203-229.

Verbong, G.P.J., van Selm, A., Knoppers, R., Raven, R., 2001. Een kwestie van lange adem; De geschiednis van duurzame energie in Nederland. Boxtel.

Vermaat, H., 1999. Demonstratie-installatie vergist rest 'grijs' afval'. Chemisch2Weekblad (23), 16-17.
Vos, d.R.C.J., 1994. Reparatie van forse bezuiniging is nu eerste prioriteit; Energiewereld likt de wonden. Energie \& MilieuSpectrum 11, 28.

Wijland, G.v., 2004. Dik Tommel nieuwe voorzitter Platform Bio-Energie: 'Bio-energie moet zwaarwegend maatschappelijk belang worden. Duurzame Energie 3, 14.

Zoeten, G.d., Zeeuw, J.H.d., Huisman, H., 1992. Scheiden/vergistem reeel alternatief naast verbranden afval. Energie \& Milieutechnologie (4), 16-19.

Zoethout, T., 2004. Biogas voor boeren eindelijk aantrekkelijk. Stromen 10 (6), 4. 